\title{
МОДЕЛЮВАННЯ РУХУ ФЛАКОНА ПО ПОХИЛИХ ПОВЕРХНЯХ У ФАРМАЦЕВТИЧНОМУ ВИРОБНИЦТВІ
}

\author{
Н. О. Кравець
}

\begin{abstract}
АВНЗ "Тернопільський державний медичний університет імені І.Я.Горбачевського"
У статті розглянуто особливості переходу флаконів різного діаметра на перехідні містки з похилими робочими поверхнями, побудовано математичні моделі, які враховують особливості руху, встановлені критичні значення прискорення фрлаконів, при яких відбувається втрата стійкості.
\end{abstract}

Ключові слова: флакон, похила поверхня, математична модель, прискорення руху флакона.

\section{МОДЕЛИРОВАНИЕ ДВИЖЕНИЯ ФЛАКОНА ПО НАКЛОННЫМ ПОВЕРХНОСТЯМ В ФАРМАЦЕВТИЧЕСКОМ ПРОИЗВОДСТВЕ}

\section{Н. О. Кравец}

ГВУЗ

\author{
"Тернопольский государственный медицинский \\ имени И. Я. Горбачевского"
}

\begin{abstract}
В статье рассмотрено особенности перехода флаконов разного диаметра на переходные мосты с наклонными рабочими поверхностями, построены математические модели, которые учитывают особенности движения, установлены критические значения ускорения флаконов, при которых происходит потеря устойчивости.
\end{abstract}

Ключевые слова: фрлакон, наклонная поверхность, математическая модель, ускорение движения флакона

\section{MODELLING OF MOTION OF THE VIAL ON INCLINED SURFACES IN PHARMACEUTICAL PRODUCTION}

\author{
N. O. Kravets \\ SHEI "Ternopii State Medical University by I. Ya. Horbachevsky"
}

\begin{abstract}
The article discusses the features of transition vials of different diameters at the transitional bridge with sloping work surfaces, built mathematical models that take into account the peculiarities of motion, described the critical acceleration vials in which there is a loss of stability.
\end{abstract}

Key words: vial, inclined surface, mathematical model, the acceleration of vial movement.

Важливою проблемою у фармацевтичній промисловості є існуючі транспортно-технологічні системи, які вимагають реконструкції з метою підвищення продуктивності при мінімальних технічних затратах $[1,2]$.

Скорочення часу транспортування на лініях розливу ліків можна домогтися шляхом збільшення числа тягових елементів транспортерів або збільшення швидкості їх руху. Вирішення цих питань накладає ряд особливостей на рух флаконів на перехідних містках із нахиленою поверхнею. Тому актуальним $\epsilon$ питання встановлення взаємозв'язку між тарою, що транспортується, і кінематичними параметрами конвеєрних ліній, вибору геометричних параметрів та швидкісних характеристик накопичувальних пристроїв $[3,4]$.

Відомі математичні моделі $[5,6]$, які описують перехід скляної тари із одних робочих поверхонь на інші не повністю враховують особливості руху і є частковими. Особливо це стосується випадків, коли транспортуючі поверхні знаходяться під кутом одна до одної.

Задачею нашого дослідження є визначення особливостей переходу флаконів різного діаметра на перехідні містки з похилими робочими поверхнями, побудова математичних моделей, які враховують особливості руху, встановлення критичних значень прискорення флаконів, при яких відбувається втрата стійкості.

(C) Н. О. Кравець 
При побудові математичних моделей, з метою їх спрощення, що дасть можливість застосувати методи класичної механіки, введемо такі припущення: флакон є абсолютно твердим тілом і має правильну циліндричну форму; коефіцієнти тертя флаконів при взаємодії з рухомими та нерухомими поверхнями $є$ сталими і не залежать від відносних швидкостей ковзання [5].

Розглянемо рух флакона по нахиленій площині i визначимо значення параметрів на початку переходу на горизонтальну робочу поверхню (рис. 1). Рівняння руху флакона по нахиленій площині буде мати вид:

$$
\vec{F}_{m p}+\vec{G}+\vec{N}=m \cdot \vec{a},
$$

де $\vec{F}_{m p}-$ сила тертя. Враховуючи рушійну силу $\vec{F}_{p}=\vec{G} \cdot \sin (\alpha)$ та умову

pyxy

$(\sin (\alpha)>\cos (\mu \cdot \alpha))$ де $\alpha$ - кут нахилу площини до горизонтальної робочої поверхні). Кінцева швидкість руху флакона по нахиленій площині визначається з умови:

$$
\frac{m v_{k}^{2}}{2}-\frac{m v_{n}^{2}}{2}=F_{\text {рівн. }} \cdot \ell,
$$

де 1 - довжина нахиленої площини.
Звідси:

$v_{k}=\sqrt{\frac{2}{m}\left(\frac{m v_{n}^{2}}{2}+F_{\text {piвн. }} l\right)}=\sqrt{v_{n}^{2}+\frac{2}{m}(m g \sin \alpha-\mu m g \cos \alpha) l}=$

$=\sqrt{v_{n}^{2}+2 g\left(h-\mu \sqrt{l^{2}-h^{2}}\right)}$

де к - висота підйому, м; I - довжина нахиленої площини, м; $V_{n}, V_{k}$ - відповідно початкова і кінцева швидкості руху флакона по нахиленій площині, м/с.

При рухові флакона по похилій поверхні на неї діють сила тяжіння і сила інерції. Умовою стійкості є (рис. 1): $\beta \geq \gamma$, де $\gamma$ - • кут між лініями дії сили тяжіння і рівнодіючої $P ; \beta$ - кут між лініями дії сили тяжіння і лінією, що з'єднує центр мас i точку $A_{\}}\left(A_{2}\right)$ [5]; ( $\gamma=\operatorname{arctg} \frac{P_{i}}{g}-$ де $P_{i}-$ сила інерції центра маси флакона; $\beta=\operatorname{arctg} \frac{d_{0}}{2 H}$, де $d_{0}$ - діаметр опорної поверхні флакона, $H$ - відстань від дна до центра мас флакона, тобто, $x_{\phi} \leq g \frac{d_{0}}{2 H}$, де $a_{\phi}$ - прискорення центра мас флакона.

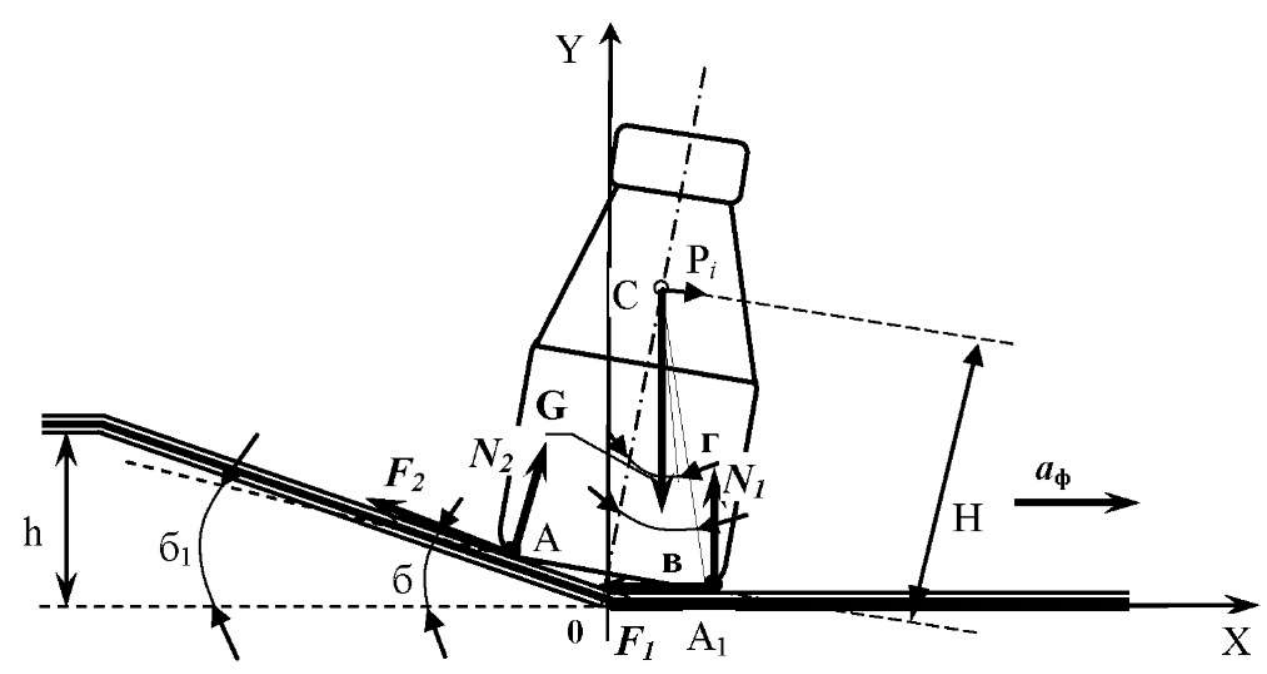

Puc. 1. Розрахункова схема випадку переходу флакона із похилої площини на горизонтальну.

3 іншої сторони, для отримання стійкості при переході з похилої поверхні на горизонтальну, прискорення центра мас флакона а повинне відповідати умові: $a_{\phi} \leq \mu \cdot g$, де $\mu \cdot g$ - характеризує сили тертя, які діють на флакон при переході на горизонтальну поверхню.
Приймаючи рух флакона як одне ціле, при початкових умовах: ${ }^{t} 0=0 ; \quad x_{0}=0 ; \quad \dot{x}=V_{k}$, рівняння руху отримує вид:

$$
m \ddot{x} \frac{d \cos \alpha+d}{d}=\mu m g \frac{x+d}{d}+\mu m g \cos \alpha \frac{x+d \cos \alpha}{d}
$$


Перетворивши вираз (4) у форму, звичну для інтегрування, отримуємо:

$\ddot{x}-\frac{\mu \cdot g}{d} x=\mu \cdot g \cdot \frac{1+\cos ^{2} \alpha}{1+\cos \alpha}$

Загальний розв'язок диференціального рівняння (5):

$x=A \sin \sqrt{\frac{\mu g}{d}} t+B \cos \sqrt{\frac{\mu g}{d}} t+d \frac{1+\cos ^{2} \alpha}{1+\cos \alpha}$.

Здійснивши підставлення початкових умов, знайдемо константи інтегрування: $A$ та $\mathrm{B}$ :

$B=0 ; \quad A=V_{k} \sqrt{\frac{d}{\mu g}}$.

Частковий розв'язок рівняння (5) отримує вид:

$x=V_{k} \sqrt{\frac{d}{\mu g}} \sin \sqrt{\frac{\mu g}{d}} t+d \frac{1+\cos ^{2} \alpha}{1+\cos \alpha}+d \frac{1+\cos ^{2} \alpha}{1+\cos \alpha}$

$\dot{x}=V_{k} \cos \left(\sqrt{\frac{\mu g}{d}} t\right) ; \ddot{x}=-V_{k} \sqrt{\frac{\mu g}{d}} \sin \left(\sqrt{\frac{\mu g}{t}} t\right)$.

Час руху флакона до повної зупинки на горизон-

тальній площині $(\dot{x}=0)$ буде: $t=\frac{1}{2} \pi \sqrt{\frac{d}{\mu g}}$.

Розглянемо рух флакона у системі відносно центра мас, тобто дослідимо випадок, коли флакон втратить динамічну стійкість на етапі переходу з похилої поверхні на горизонтальну робочу поверхню (рис. 1).

Загальне рівняння руху флакона буде мати вид:

$-F_{1}-F_{2} \cos \alpha+N_{2} \sin \alpha-m \ddot{x}_{c}=0$;

$N_{1}+N_{2} \cos \alpha+F_{2} \sin \alpha-m g-m \ddot{y}_{c}=0$;
$I \ddot{\alpha}_{1}=N_{1} H \frac{\sin \left(\alpha+\alpha_{1}\right)}{\cos \beta}-F_{1} H \frac{\cos \left(\alpha+\alpha_{1}\right)}{\cos \beta}+N_{2} H \frac{\sin \left(\alpha+\alpha_{1}\right) \sin \alpha}{\cos \alpha}+$

$+F_{2} H \frac{\cos \left(\alpha+\alpha_{1}\right) \cos \alpha}{\cos \alpha}$.

де (6) і (7) - рівняння, що характеризують прискорення центра мас в проекціях на осі вибраної системи координат, відповідно; (8) - рівняння моменту інерції флакона при переході на горизонтальну площину; $F_{1}, F_{2}$. сили тертя флакона на площинах в момент переходу; $N_{p} N_{2}$ - нормальні складові реакції площин на флакон; $H$ - відстань від дна до цен-

трамасфлаконаё $\ddot{c}_{c}, \ddot{y}_{c}$ - значення прискорення центрамасстакона в проекціях на оа вибраної системи координат; $\ddot{\alpha}_{1}$ - кутова координата фртакана при їі обєргєнні; I - момент інерції центра мас флакона.

При відомому значенні моменту інерції флакона $\left(I_{\phi}=m\left(H^{2}+d^{2}\right)\right)$ після підставлень і перетворень, прискорення кутової координати флакона отримує вид:

$\ddot{\alpha}_{1}=\frac{1}{H^{2}+d^{2}} \cdot\left(\frac{P^{2}}{H} \alpha_{1}^{2}(H+d-\operatorname{dctg} \alpha)+P \mu \operatorname{ctg} \alpha\left(\alpha+\cos \alpha+\frac{X_{A_{1}}}{\mu g}\right)+\right.$

$\left.P g\left(\mu \sin \alpha-\frac{X_{A_{1}}}{g}+\mu \sin \alpha \cos \alpha-\mu-1\right)\right)$

$$
\text { де } P=\frac{H \cos \left(\alpha-\alpha_{1}\right)}{\cos \alpha} ; \quad \ddot{X}_{A_{1}}=-V_{k} \sqrt{\frac{\mu g}{d}}
$$

Розв'язок диференціального рівняння (9) за допомогою розробленого програмного забезпечення дав можливість: обчислити мінімальний кут нахилу похилої площини, при якому флакон повністю перейде на горизонтальну площину; прискорення

Puc. 2. Залежність зміни початкової швидкості флакону на нахиленій площині від маси флакону (зміни висоти центра мас):

$1-d=0,032$ м ( $\sigma_{\text {onm }}=11,59$ град); $2-d=$ $0,038 \mathrm{M}\left(\sigma_{\text {onm }}=11,64\right.$ град); $3-d=0,032 \mathrm{M}$ $\left(\sigma_{\text {onm }}=11,67\right.$ гpad $)$.

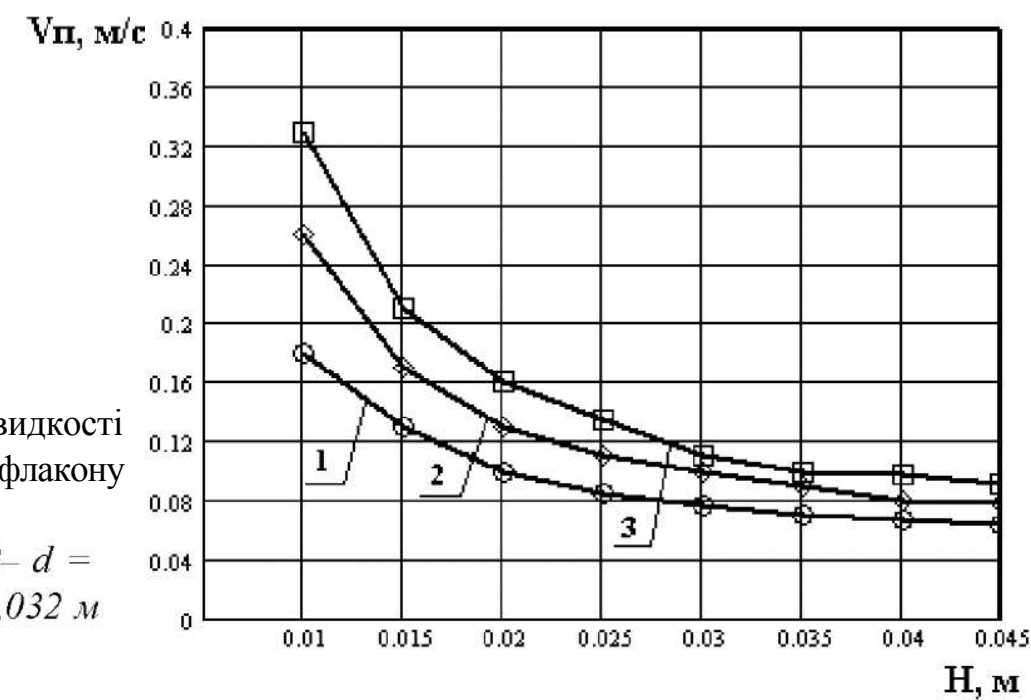


флакона при рухові по нахиленій площині без втрати динамічної стійкості при переході на горизонтальну.

В реальних умовах, визначивши раціональний кут нахилу площини в залежності від діаметра тари, прискорення флакона на конвеєрній лінії можливо регулювати шляхом задання початкової швидкості на перехідних містках $\left(y_{n}\right)$.

Розрахунок проводився із заданням вихідних даних реальної потокової лінії $(l=0,7 \mathrm{M} ; \mu=0,2$; фллакони діаметрами (м) 0,042; 0,038; 0,032. На рис. 2 представлена залежність зміни початкової швидкості руху

\section{Література}

1. Иванченко Ф. К. Конструкция и расчет подъемно-транспортных машин / Ф. К. Иванченко - К. : Виша школа. 1988-416 с. 2. Соколенко А.И. Погрузочно-разгрузочные и транспортные операции на линях розлива пищевых продуктов / А. И. Соколенко, М. И. Юхно, А. И. Ковалев - М. : Агропро- флакона по похилій площині ( $\mathrm{y}_{\text {п }}$ ) від маси флакона (зміна висоти центра мас $H$ ) при різних значеннях діаметра флакона.

Висновки: 1. Запропонована математична модель руху флакона по похилій площині із переходом на горизонтальну дозволяє знаходити мінімальний кут нахилу похилої площини, визначати початкову швидкість

руху флакона $\mathrm{Y}_{\text {п }}$ та час процесу переходу.

2. За умови, що горизонтальна поверхня являє собою конвеєр, отримано можливість визначити оптимальну швидкість конвеєра без затримки руху на переході із похилої площини на горизонтальну.

миздат, 1986. - 176c.

3. Соколенко А.И. Погрузочно-разгрузочное и транспортное оборудование в перерабатывающей промышленности. Справочник / А. И. Соколенко, И. И. Сторижко и др. - К. : Урожай. - 1990. - 152 с. 